Check for updates

Cite this: RSC Adv., 2017, 7, 48639

Received 15th August 2017

Accepted 9th October 2017

DOI: $10.1039 / c 7 r a 09038 b$

rsc.li/rsc-advances

\section{Enzymatic ring-opening polymerization (ROP) of lactides and lactone in ionic liquids and organic solvents: digging the controlling factors $\dagger$}

\begin{abstract}
Hua Zhao, (D) *ab Gabrielle A. Nathaniel ${ }^{b}$ and Princess C. Merenini ${ }^{b}$
Polylactides (PLAs) and polylactones are sustainable and biodegradable polymers with important applications in packaging, horticultural materials, and biomedical fields. The enzymatic ring-opening polymerization (ROP) method represents a 'green' approach to the synthesis of these polyesters. However, there are lots of discrepancies in the literature on the lipase specificity towards a particular monomer (such as L-lactide), and many disagreements on the molecular weights produced by similar methods. To provide a better understanding of the key factors regulating the ROP reaction, we carried out a systematic investigation of the polymerization process under different temperatures catalyzed by different types and batches of lipases with various water contents, in different solvents including ionic liquids with known water contents, and by using different initiators. Our data clearly indicate that the key reaction parameters include the types of lipases and solvents, the amount of solvents, water contents in both enzymes and solvents, and the reaction temperature. N,N-Dimethylacetamide (DMA) and 1-butyl3-methylimidazolium hexafluorophosphate ([BMIM][PF 6$]$ ) at low concentrations were found suitable for the ROPs of lactides and $\varepsilon$-caprolactone leading to $M_{w}$ of about 20000 (polydispersity indexes mostly below 1.8) and moderately high yields (up to 60\%). Our study suggests that all of these reaction parameters need to be fully controlled during the enzymatic ROP reaction although some earlier studies often neglected some conditions (such as the exact water content in enzymes and solvents).
\end{abstract}

\section{Introduction}

Polylactide (PLA), often referred to as poly(lactic acid), is a sustainable biopolymer because the monomer lactic acid or lactide can be produced from the microbial fermentation of agricultural by-products including carbohydrate-rich substances. ${ }^{1}$ PLA and its derivatives, as an important part of aliphatic polyesters, are thermoplastic, biodegradable, renewable and biocompatible polymers with mechanical properties similar to those of polystyrene or polyethylene terephthalate. ${ }^{2}$ PLA has a wide range of applications in packaging and horticultural materials ${ }^{3}$ in addition, due to its high biocompatibility and the lack of toxicity, PLA has major uses in biomedical fields including controlled drug delivery carriers, tissue engineering scaffolds, surgical suture and bone fixation materials. ${ }^{\mathbf{1} 4-6}$

There are several common routes for preparing PLA but each of them has some drawbacks: (a) a direct polycondensation polymerization usually results in a low molecular weight PLA

${ }^{a}$ Department of Chemistry and Biochemistry, University of Northern Colorado, Greeley, CO 80639,USA.E-mail: hua.zhao@unco.edu; huazhao98@gmail.com

${ }^{b}$ Department of Chemistry and Forensic Science, Savannah State University, Savannah, GA 31404, USA

† Electronic supplementary information (ESI) available. See DOI: 10.1039/c7ra09038b with poor mechanical properties; (b) azeotropic condensation polymerization can yield high molecular weight PLA (such as $M_{\mathrm{n}}$ up to 300000$),{ }^{7}$ but this method has several disadvantages including the need for high temperature, the continuous removal of byproducts (such as water) and long reaction times; (c) solid state polymerization (SSP) operates at a temperature above the glass transition temperature but below the melting temperature, ${ }^{8}$ and has the advantage of producing high molecular weight and fine control of side reactions but requires a much longer reaction time than in melt state or solutions; (d) on the other hand, ring-opening polymerization (ROP) of lactide (LA) (cyclic dimer of lactic acid) through coordination polymerization with metal derivatives such as tin(II) octoate $\left[\mathrm{Sn}(\mathrm{Oct})_{2}\right]$ or $\operatorname{tin}(\mathrm{II})$ butoxide (PLA $M_{\mathrm{n}}$ up to $\sim 10^{6}$ ), ${ }^{9}$ anionic polymerization (such as strong bases with alcohols), or cationic polymerization is industrially preferred to achieve high molecular weight PLA in bulk (in the melt/absence of solvent); ${ }^{\mathbf{1 , 1 0}}$ however, the drawback from this option is the residues of metal catalysts in polyesters; this could be disadvantageous for medical and electronic applications although $10 \mathrm{ppm} \mathrm{Sn}(\mathrm{Oct})_{2}$ residue in PLA is generally considered to be safe. ${ }^{\mathbf{1 0}}$

Enzymatic ROP of lactides using lipases and esterases represents a 'greener' alternative to metal-based catalysts. Lipase-catalyzed polymerization of lactides has been carried out in bulk, in organic solvents (such as toluene), and recently in 
supercritical carbon dioxide $\left(\mathrm{sc}-\mathrm{CO}_{2}\right)$ and ionic liquids. ${ }^{\mathbf{1 , 6}, \mathbf{1 0}}$ Several lipases are commonly used in these reactions, such as Candida antarctica lipase B (CALB) (free form, or immobilized on acrylic resin known as Novozym 435), lipase PS from Burkholderia cepacia, Pseudomonas cepacia lipase PS, and porcine pancreatic lipase (PPL). Representative CALB-catalyzed reactions in each one of these solvents which led to high-molecularweight PLAs are briefly discussed below for comparison purpose (see our recent review ${ }^{\mathbf{1 1}}$ for details). In the absence of solvent, the Yoshizawa-Fujita group ${ }^{\mathbf{1 2}}$ carried out the free CALBcatalyzed ROP of L-lactide at $130{ }^{\circ} \mathrm{C}$, and obtained the polyester with $M_{\mathrm{w}} 40000$, polydispersity index (PDI) 1.13 and yield $54.1 \%$. When the ROP reaction in toluene was catalyzed by free CALB at $100{ }^{\circ} \mathrm{C}$ for $24 \mathrm{~h}$, Yoshizawa-Fujita et al. ${ }^{12}$ obtained PLA with $M_{\mathrm{n}}=44100$, PDI $=1.15$ and yield $=26.9 \%$. Using the biphasic system of supercritical $\mathrm{CO}_{2}$ and melted L-lactide, $M_{\mathrm{W}}$ up to 12900 of PLA was obtained when the ROP was catalyzed by Novozym 435 under a low initial water activity $\left(a_{\mathrm{w}}<0.16\right)$ at $65{ }^{\circ} \mathrm{C}^{13}$ Several common ionic liquids have been examined in the enzymatic polymerization of lactide catalyzed by CALB. The Yoshizawa-Fujita group ${ }^{12}$ carried out CALB-catalyzed ringopening polymerization of L-lactide in 1-butyl-3methylimidazolium tetrafluoroborate $\left([\mathrm{BMIM}]\left[\mathrm{BF}_{4}\right]\right)$ at $110{ }^{\circ} \mathrm{C}$, achieving $M_{\mathrm{n}} 54600,1.25$ PDI and $24.3 \%$ yield; in comparison, the solvent-free condition at $130{ }^{\circ} \mathrm{C}$ resulted in $M_{\mathrm{n}} 40000$, and $54.1 \%$ yield while toluene as the solvent at $120{ }^{\circ} \mathrm{C}$ led to $M_{\mathrm{n}}$ 42600 and $17.3 \%$ yield. This group also noted the lipase activity in the polymerization reaction decreasing with different ionic liquids as: $[\mathrm{BMIM}]\left[\mathrm{BF}_{4}\right]>[\mathrm{BMIM}]\left[\mathrm{Tf}_{2} \mathrm{~N}\right]>[\mathrm{BMIM}]\left[\mathrm{PF}_{6}\right]>[\mathrm{BMIM}]$ [dca] $\left(\mathrm{Tf}_{2} \mathrm{~N}^{-}=\right.$bis(trifluoromethylsulfonyl)imide, and $\mathrm{dca}^{-}=$ dicyanamide). Several other studies also reported a lower degree polymerization of lactide in [BMIM] $\left[\mathrm{PF}_{6}\right]$, such as $M_{\mathrm{n}} 581$ and 29.5 yield at $65{ }^{\circ} \mathrm{C},{ }^{14}$ and $M_{\mathrm{n}} 19600$ at $90{ }^{\circ} \mathrm{C}$; however, a higher molecular weight $M_{\mathrm{n}}$ of 37800 and a higher yield of $63.2 \%$ were achieved in [HMIM] $\left[\mathrm{PF}_{6}\right]$ at $90{ }^{\circ} \mathrm{C}^{\mathbf{1 5}}$

On the other side, there have been inconsistent reports on "which enzyme is more active towards L-lactide?" and "what is the role of solvents?". As summarized in Table S1 (ESI $\dagger$ ), most reactions were conducted under so called "dry conditions", but the exact water contents in solvents, enzymes and monomers were not determined. It is well known that water is the initiator of the ROP reaction, but an excess amount of water leads to the enzymatic hydrolysis of polyester. ${ }^{\mathbf{6}, 16,17}$ In addition, there have been mixed reports on the lipase specificity on $\mathrm{L}^{-}$and $\mathrm{D}^{-l a c t i d e .}$ Matsumura et al. ${ }^{18}$ observed no activity of Novozym 435 toward the ROP of D,L-lactide, but a high activity for Pseudomonas cepacia lipase PS and a modest activity for Cundidu cylindruceu lipase and porcine pancreatic lipase (PPL). Under the optimum conditions, lipase PS gave weight-average molecular weights $\left(M_{\mathrm{w}}\right)$ up to 126000 and $16 \%$ yield at $130^{\circ} \mathrm{C}$. This group ${ }^{19}$ further demonstrated that PPL exhibited a high activity for the copolymerization of lactide and trimethylene carbonate, resulting in $M_{\mathrm{w}}$ up to 21000 and $40 \%$ yield. Therefore, it is suggested ${ }^{20,21}$ that CALB has a better selectivity toward D-lactide than L-isomer, whilst lipase from Burkholderia cepacia (known as lipase PS) is more specific toward L-lactide. Duchiron et al. ${ }^{\mathbf{2 1}}$ indicated that the addition of triethylamine could activate the lipases, resulting in $4900 M_{\mathrm{n}}$ and $89 \%$ yield for Novozym 435-catalyzed ROP of D-lactide, and $1800 M_{\mathrm{n}}$ and $80 \%$ yield for lipase PScatalyzed ROP of L-lactide. On the contrary, a number of studies still reported the synthesis of relatively high molecular weights of polylactide catalyzed by Novozym 435 in organic solvents and ionic liquids (see Table $\mathbf{S} 1 \dagger$ ). For example, Omay et $a{ }^{22}$ carried out the polymerization of $\mathrm{D}, \mathrm{L}$-lactide in dry toluene at $80{ }^{\circ} \mathrm{C}$, and obtained $M_{\mathrm{n}}$ of 26000 and 21000 when using Novozym 435 and free CALB, respectively.

To clarify the inconsistent results of the enzymatic ROP of lactides, we aim to examine some key factors of the ROP reaction including different organic solvents and ionic liquids, water contents in the reaction system, different lipases and initiators. These evaluations will provide some guidance towards the future rational design of the enzymatic polymerization for polyester synthesis.

\section{Experimental section}

\section{Materials}

The items purchased from Sigma-Aldrich include L-(-)-lactide (catalog \# 367044), DL-lactide (catalog \# 303143), lipase from Pseudomonas fluorescens (Sigma 534730, Batch \# MKCB1125V), Candida antarctica lipase B (CALB) immobilized on acrylic resin known as Novozym 435 (catalog \# L4777), Candida antarctica lipase B (catalog \# 62288), CALB immobilized on Immobead 150 (catalog \# 54326), CALB-CLEA (Cross-Linked Enzyme Aggregate) (catalog \# 16698), Amano lipase PS from Burkholderia cepacia (catalog \# 534641), Amano lipase from Pseudomonas fluorescens (catalog \# 534730), lipase from porcine pancreas (PPL) type II (catalog \# L3126), Amano lipase A from Aspergillus niger (catalog \# 534781), lipase from Pseudomonas cepacia immobilized in solgel-AK (catalog \# 62279), lipase from Candida cylindracea immobilized in sol-gel-AK (catalog \# 62278), and Resomer® R203H poly(D,L-lactide) (catalog \# 719943, Lot \# STBF1681V) with $M_{\mathrm{w}}$ 18 000-24 000. Lipase PS-C Amano I (catalog \# ILPSAC0350403R) and lipase PS-D Amano I (catalog \# ILPSAB0152305R) were kind gifts from Amano Enzyme USA (Elgin, IL). D-(+)-Lactide obtained from Sigma-Aldrich was a product of Ark Pharm (catalog \# AK57455). $\varepsilon$-Caprolactone was acquired from TCI America. Anhydrous dimethylformamide (DMF, 99.8\%) was obtained from Alfa Asear (Ward Hill, MA). 1-Butyl-3-methylimidazolium hexafluorophosphate ([BMIM] $\left[\mathrm{PF}_{6}\right]$, high purity), 1-butyl-3methylimidazolium bis(trifluoromethylsulfonyl)imide ([BMIM] $\left[\mathrm{Tf}_{2} \mathrm{~N}\right]$, synthesis grade), and 1-butyl-3-methylimidazolium tetrafluoroborate ([BMIM] $]\left[\mathrm{BF}_{4}\right]$, high purity) obtained from VWR were products of Merck KGaA (EMD Millipore Corporation, Billerica, MA). Cholinium bis(trifluoromethylsulfonyl)imide ([Choline] $\left.\left[\mathrm{Tf}_{2} \mathrm{~N}\right]\right)$, triethyl (2-(2-methoxyethoxy)ethoxy)ethylammonium bis(trifluoromethanesulfonyl)imide $\quad\left(\left[\mathrm{CH}_{3}\left(\mathrm{OCH}_{2} \mathrm{CH}_{2}\right)_{3}-\mathrm{Et}_{3} \mathrm{~N}\right]\right.$ $\left.\left[\mathrm{Tf}_{2} \mathrm{~N}\right]\right)$, triethyl (2-(2-methoxyethoxy)ethoxy)ethylammonium acetate $\left(\left[\mathrm{CH}_{3}\left(\mathrm{OCH}_{2} \mathrm{CH}_{2}\right)_{3}-\mathrm{Et}_{3} \mathrm{~N}\right][\mathrm{OAc}]\right)$, 1-ethyl-3-(2-(2-methoxyethoxy)ethoxy)ethyl)piperidinium bis(trifluoromethanesulfonyl) imide ([ $\mathrm{CH}_{3}\left(\mathrm{OCH}_{2} \mathrm{CH}_{2}\right)_{3}$-Et-Pip] $\left.\left[\mathrm{Tf}_{2} \mathrm{~N}\right]\right)$, 1-ethyl-3-(2-(2-methoxyethoxy)ethoxy)ethyl)piperidinium acetate $\left(\left[\mathrm{CH}_{3}\left(\mathrm{OCH}_{2} \mathrm{CH}_{2}\right)_{3}\right.\right.$-EtPip][OAc]) were prepared and characterized in our earlier studies. $^{23,24}$ 


\section{Methods}

Enzymatic ROP of lactide. The water contents of all solvents, monomers and enzymes were determined by the Karl Fischer (KF) titration (Mettler Toledo C20X compact Coulometric titrator with the detection limit of $1 \mathrm{ppm}$ water) at $20{ }^{\circ} \mathrm{C}$. Hydranal ${ }^{\circledR}$ Coulomat AG was used as the analyte for the titration. A typical reaction condition is described as the following: the substrate ( $0.5 \mathrm{~g}$ of $\mathrm{L}$-lactide, D-lactide, or DL-lactide) was mixed with $0.25 \mathrm{~mL}$ solvent, followed by the addition of $100 \mathrm{mg}$ Novozym 435. The reaction mixture was sealed tightly and stirred at $130{ }^{\circ} \mathrm{C}$ in oil bath. At the completion of reaction, the reaction mixture was cooled to room temperature and then $2.0 \mathrm{~mL} \mathrm{CDCl}_{3}$ was added to dissolve the polyester under vigorous agitation. For ${ }^{1} \mathrm{H}$ NMR analysis, $50 \mu \mathrm{L}$ reaction aliquot was withdrawn and diluted with $1.0 \mathrm{~mL} \mathrm{CDCl}_{3}$ followed by centrifugation. For gel permeation chromatography (GPC) analysis (a type of size exclusion chromatography, SEC), $50 \mu \mathrm{L}$ reaction aliquot was withdrawn and diluted with $1.0 \mathrm{~mL}$ THF, and the mixture was centrifuged before the GPC injection (see GPC conditions below in Polymer characterization). To obtain the solid product, after evaporating chloroform, the polymer was precipitated by adding ice-cold methanol and was separated by centrifugation or vacuum filtration. The polyester was air-dried for $24 \mathrm{~h}$.

The overall water content of the reaction mixture was determined by mixing the reaction mixture (monomer, lipase and solvent) with $5.0 \mathrm{~mL}$ anhydrous methanol under gentle stirring at room temperature for $24 \mathrm{~h}$. The water contents in methanol before and after the mixing were determined by the Karl Fischer titration. The overall water content in the reaction mixture was calculated from the water contents in methanol before and after the mixing.

Enzymatic ROP of $\varepsilon$-caprolactone. The substrate $\left(0.5 \mathrm{~g}\right.$ of $\varepsilon^{-}$ caprolactone; density $1.03 \mathrm{~g} \mathrm{~mL}^{-1}$ ) was dissolved in $0.25 \mathrm{~mL}$ solvent, followed by the addition of $100 \mathrm{mg}$ Novozym 435 . The reaction mixture was sealed tightly and stirred at $70{ }^{\circ} \mathrm{C}$ in oil bath. At the completion of reaction, the reaction mixture was cooled to room temperature and then $2.0 \mathrm{~mL} \mathrm{CDCl}_{3}$ was added to dissolve the polyester under vigorous agitation. For NMR analysis, $50 \mu \mathrm{L}$ aliquot was withdrawn and diluted with $1.0 \mathrm{~mL}$ $\mathrm{CDCl}_{3}$ following by centrifugation. For GPC analysis, $50 \mu \mathrm{L}$ aliquot was withdrawn and diluted with $1.0 \mathrm{~mL} \mathrm{THF}$, and the mixture was centrifuged before GPC injection (see GPC conditions below in Polymer characterization). To obtain the solid product, after evaporating chloroform, the polymer was precipitated by adding ice-cold methanol and was separated by centrifugation or vacuum filtration. The polymer was air-dried for $24 \mathrm{~h}$.

Polymer characterization. The lactide conversion was monitored by ${ }^{1} \mathrm{H}$ NMR by comparing the peak area of methine group $(\mathrm{CH})$ adjacent to carbonyl group in the monomer (5.04 $\mathrm{ppm}$ ) and in the polymer (5.16 ppm). ${ }^{12}$ Monomer $\varepsilon$-caprolactone conversion was determined by ${ }^{1} \mathrm{H}$ NMR by comparing the integrated signal areas of the methylene groups next to the carbonyl group in the monomer $\varepsilon$-caprolactone (CL) $(4.23 \mathrm{ppm})$ and $\operatorname{poly}\left(\varepsilon\right.$-caprolactone) PCL $(4.07 \mathrm{ppm}) .{ }^{25}$ In addition, the degree of polymerization (DP) was estimated from the ratio of integration of the signal at $4.07 \mathrm{ppm}$ assigned to the $\mathrm{CH}_{2} \mathrm{O}$ groups of PCL main chain to the integration of the signal at 3.6$3.7 \mathrm{ppm}$ assigned to the chain-end $\left(\mathrm{CH}_{2} \mathrm{OH}\right.$, and $\left.\mathrm{CH}_{3} \mathrm{O}\right)$, which led to the calculation of $M_{\mathrm{n}, \mathrm{NMR}}=\left[\left(5 \times I_{4.07}\right) /\left(2 \times I_{3.66}\right)\right] \times M_{\varepsilon-}$ $\mathrm{CL}^{26,27}$ The molecular weight $\left(M_{\mathrm{w}}\right)$ and PDI of the polyester were determined by GPC equipped with a LC-20AT Shimadzu HPLC with SPD-20A UV-visible dual-wavelength and refractive detectors, two PLgel MIXED-B $10 \mu \mathrm{m}, 300 \times 7.5 \mathrm{~mm}$ columns (Agilent) eluted with $1.0 \mathrm{~mL} \mathrm{~min}^{-1} \mathrm{THF}$ at $40{ }^{\circ} \mathrm{C}^{28}$ Calibration was achieved by using polystyrene standards from 570 to 62500 $\left(M_{\mathrm{w}}\right) \cdot{ }^{22}$ The polyester structure was also confirmed by ${ }^{1} \mathrm{H}$ and ${ }^{13} \mathrm{C}$ NMR (JEOL $300 \mathrm{MHz}$ ) in $\mathrm{CDCl}_{3}$ and FT-IR (Shimadzu IR Prestige-21). ${ }^{12,22,29-32}$ The specific optical rotation of the polymers, $[\alpha]$, was determined in chloroform at a concentration of $10 \mathrm{mg}$ $\mathrm{mL}^{-1}$ at room temperature using a Rudolph Autopol III polarimeter at the wavelength of $589 \mathrm{~nm}$.

Circular dichroism (CD) spectra of CALB. Free CALB was dissolved in phosphate buffer (50 mM, pH 7.0) to make a $0.1 \mathrm{mg}$ $\mathrm{mL}^{-1}$ solution. The background CD spectrum was scanned with the corresponding buffer. An aliquot of the mixture was scanned in the range of 190-250 $\mathrm{nm}$ (far UV) by a JASCO J-825 CD Spectrometer (Tokyo, Japan) purged by $\mathrm{N}_{2}$. The instrument parameters were set as the following: data pitch $0.1 \mathrm{~nm}$, scanning speed $100 \mathrm{~nm} \min ^{-1}$, band width $1.00 \mathrm{~nm}$, slit width 100 um, DIT $1 \mathrm{~s}$, standard sensitivity, 5 accumulations, and the cell temperature of $25{ }^{\circ} \mathrm{C}$.

\section{Results and discussion}

In our experiments, the water contents in all lipases, monomers and solvents were determined by the Karl Fisher titration with the detection limit of 1 ppm water (see Table S2 in ESI $\dagger$ ). All solvents were obtained as the anhydrous grade or the high purity grade with the lowest possible water content. In this study, molecular weights $\left(M_{\mathrm{w}}\right.$ and $\left.M_{\mathrm{n}}\right)$ were determined by GPC analysis using polystyrene calibration; those of poly( $\varepsilon$-caprolactone) were also determined by ${ }^{1} \mathrm{H}$ NMR analysis.

\section{Effect of water content in lipases on ROP}

Water molecules associated with enzymes (including lipases) could be classified into two categories: water at the surface layer of enzyme molecules is called 'essential water' (or 'free water', or 'hydration water'), and water buried inside enzyme molecules is known as the 'bond water' (or 'structural water'). ${ }^{21,33,34}$ It was observed that under intensive drying over $\mathrm{P}_{2} \mathrm{O}_{5}$, lysozyme and subtilisin Carlsberg lost the layer of 'essential water', but still kept 3-4 and 14-16 structural water molecules per enzyme molecule, respectively. ${ }^{35}$ Since the Karl Fischer titration only determines 'free water' available in the solution, not any trapped or inaccessible water to the Karl Fischer reagents; ${ }^{33,36}$ therefore, it is most likely that only the 'free water' could be determined by the Karl Fischer titration. Table 1 reports the ('free') water contents in different batches of commercial Novozym 435, and in immobilized lipases calibrated with different thermodynamic water activities $\left(a_{\mathrm{w}}=0.11\right.$ via 
Table 1 Effect of different batches of Novozym 435 on ROP of L-lactide ${ }^{a}$

\begin{tabular}{|c|c|c|c|c|c|c|}
\hline Trial & N435 batch \# (purchase date) & Enzyme water (\%) & Conversion (\%) & Yield (\%) & $M_{\mathrm{w}}$ & PDI \\
\hline 1 & 097K1155 (05/2009) & 0.77 & 93.5 & 20 & 17000 & 1.71 \\
\hline 2 & & $2.62\left(a_{\mathrm{w}} 0.11\right)$ & 85.0 & 22 & 14600 & 1.68 \\
\hline 4 & 067 K3522 (09/2009) & 1.09 & 84.9 & 33 & 13400 & 1.72 \\
\hline 5 & & $2.52\left(a_{\mathrm{w}} 0.11\right)$ & 91.0 & 18 & 10900 & 1.65 \\
\hline 6 & SLBP0766V (03/2016) & 1.09 & 63.0 & 12 & 11500 & 1.41 \\
\hline 9 & SLBS9524 (03/2017) & 1.94 & 72.0 & 30 & 8600 & 1.52 \\
\hline 10 & & 1.94 (14 days) & 87.3 & 28 & 12700 & 1.50 \\
\hline 11 & & $2.38\left(a_{\mathrm{w}} 0.11\right)$ & 70.9 & 28 & 8300 & 1.44 \\
\hline 12 & & $2.77\left(a_{\mathrm{w}} 0.33\right)$ & 71.9 & 28 & 8100 & 1.47 \\
\hline 13 & Novozym (05/2017) & 1.97 & 56.4 & 32 & 9672 & 1.44 \\
\hline
\end{tabular}

${ }^{a}$ Note: reactions conditions: $0.5 \mathrm{~g}$ lactide, $0.25 \mathrm{~mL}$ [BMIM] $\left[\mathrm{PF}_{6}\right]\left(0.02 \mathrm{wt} \%\right.$ water), $100 \mathrm{mg}$ Novozym 435 (Sigma L4777), gentle stirring at $130{ }^{\circ} \mathrm{C}$ for 7 days. $M_{\mathrm{w}}$ values were determined by GPC as calibrated by polystyrene standards.

equilibrium with saturated LiCl solution, and $a_{\mathrm{w}}=0.33$ via equilibrium with saturated $\mathrm{MgCl}_{2}$ solution). ${ }^{37-39}$ The 'free water' contents in commercial Novozym 435 range from 0.77-1.97 wt\% among those five batches in Table 1 (trials 1, 4, 6, 9, and 13). The enzymatic ROP of L-lactide was catalyzed by different batches of Novozym 435 using a small amount $(0.25 \mathrm{~mL})$ of [BMIM] $\left[\mathrm{PF}_{6}\right]$ (containing $0.02 \mathrm{wt} \%$ water). In general, the molecular weight of PLA decreases (trials $1>4,6>9,13$ ) with the increase in initial water content in the immobilized lipase. When the enzyme was exposed to saturated LiCl solution $\left(a_{\mathrm{w}}=0.11\right)$, the lipase's water content increased to $2.26-2.62 \mathrm{wt} \%$, and the molecular weight of PLA slightly decreased (trial 2 vs. 1, 5 vs. 4, 7 vs. 6, and 11 vs. 9 in Table 1). The Gross group ${ }^{33}$ varied the water contents (e.g. 0.6, 1.15 and $1.95 \mathrm{wt} \%$ ) of Novozym 435 and found a higher water content resulted in a lower molecular weight of PCL. The Sayer group ${ }^{40}$ indicated that drying Novozym 435 (the water content decreased from $1.74 \mathrm{wt} \%$ to $0.77 \mathrm{wt} \%$ ) lead to a drop in polyester yield but an increase in molecular weight during the ROP of $\omega$-pentadecalactone in supercritical $\mathrm{CO}_{2}$ using dichloromethane or chloroform as co-solvent. On the other hand, when the thermodynamic water activity further increased to $a_{\mathrm{w}}=0.33$ (2.77-3.62 wt\% water), the PLA's molecular weight maintained unchanged (such as trials 3 and 12 in Table 1 when comparing with those at $a_{\mathrm{w}}=0.11$ ), or even increased (trial 8). Therefore, the free water content in the enzyme plays a critical role in the enzymatic polymerization reaction.

\section{Effect of different solvents and water contents on ROP}

The enzymatic ROP of L-lactide catalyzed by Novozym 435 was evaluated with the presence of different co-solvents (see Table 2, trials 1-3 for solvent-free/in bulk, 4-25 for organic solvents, and 26-44 for ionic liquids). At first, we noted that a higher temperature (e.g. $130{ }^{\circ} \mathrm{C}$ ) led to higher molecular weights and conversions than lower temperatures $\left(80-110{ }^{\circ} \mathrm{C}\right)$ either in bulk (trial 2 and 3 vs. 1), in triglyme (trial $8 v s$. 7), or in [BMIM] $\left[\mathrm{PF}_{6}\right]$ (trial $36 v s .34$ and 35). Thus, we selected $130{ }^{\circ} \mathrm{C}$ as the reaction temperature for this polymerization process in most studies. The baseline data established by the reaction without any solvent (trial 3 in Table 2) were $M_{\mathrm{w}} 16$ 900, PDI 1.75, conversion $72.2 \%$, and isolated yield $14 \%$. A variety of organic solvents were examined as media of the ROP reactions, including toluene, xylene, $N, N$-dimethylformamide (DMF), triglyme, tetraglyme, 1methyl-2-pyrrolidone, and $N, N$-dimethylacetamide (DMA) because most of them have boiling points above $130{ }^{\circ} \mathrm{C}$ (except toluene $110{ }^{\circ} \mathrm{C}$ ). Most organic solvents led to much lower molecular weights and yields than that in bulk (16 900, 14\% yield) except those in xylene (16 300, 42\%, but a higher PDI 2.03) and in DMA (trials 15-25 in Table 2). DMA seems to be an exceptionally benign solvent for this enzymatic polymerization reaction, affording the highest $M_{\mathrm{w}} 18300$ (with 20\% yield and PDI 1.68, in trial 23) after 14 days of reaction. Novozym 435 recycled from the ROP reaction in DMA showed lower molecular weights of PLA being produced (trials 24 and 25), but the enzyme still retained certain activities after the vigorous reaction condition (unlike in bulk or in other organic solvents, the enzyme typically turned into char after the reaction). Most ionic liquids (26-44) failed to produce a higher molecular weight and/ or yield comparing with the solvent-free condition except [BMIM] $\left[\mathrm{PF}_{6}\right]$, where the highest $M_{\mathrm{w}}$ observed was 17000 (with $20 \%$ yield and PDI 1.71, in trial 36 ). In addition to the type of solvents, the amount of solvents is also crucial to the enzymatic ROP process. When comparing different amounts of solvents (trials 10/11/12 in 1-methyl-2-pyrrolidone, 16/20/21 in DMA, 36/ $40 / 41$ in [BMIM] $\left[\mathrm{PF}_{6}\right]$ ), a lower solvent content (such as $0.25 \mathrm{~mL}$ for $0.5 \mathrm{~g}$ L-lactide) seems beneficial to produce higher molecular weights (except trial 41). However, if no solvent is present, the oligo(lactide) easily solidifies which creates the mass transfer barrier for continuing the enzymatic reaction.

Earlier studies might provide some insights of why the enzymatic ROP reactions were not successful in most ionic liquids but in $\left[\mathrm{BMIM}\left[\mathrm{PF}_{6}\right]\right.$. The Monticelli group ${ }^{41}$ studied the melt-blending of PLA with an imidazolium IL (e.g. [BMIM]Cl, [BMIM]I, or $\left.[\mathrm{BMIM}]\left[\mathrm{PF}_{6}\right]\right)$, and found PLA could be miscible with up to $10 \%$ [BMIM $]\left[\mathrm{PF}_{6}\right]$ by mass; in addition, $[\mathrm{BMIM}]\left[\mathrm{PF}_{6}\right]$ induced the lowest amount of decomposition of polymer matrix during the melt-blending process (at $180-230{ }^{\circ} \mathrm{C}$ ), and even 
Table 2 Enzymatic ROP of lactides under different reaction conditions ${ }^{a}$

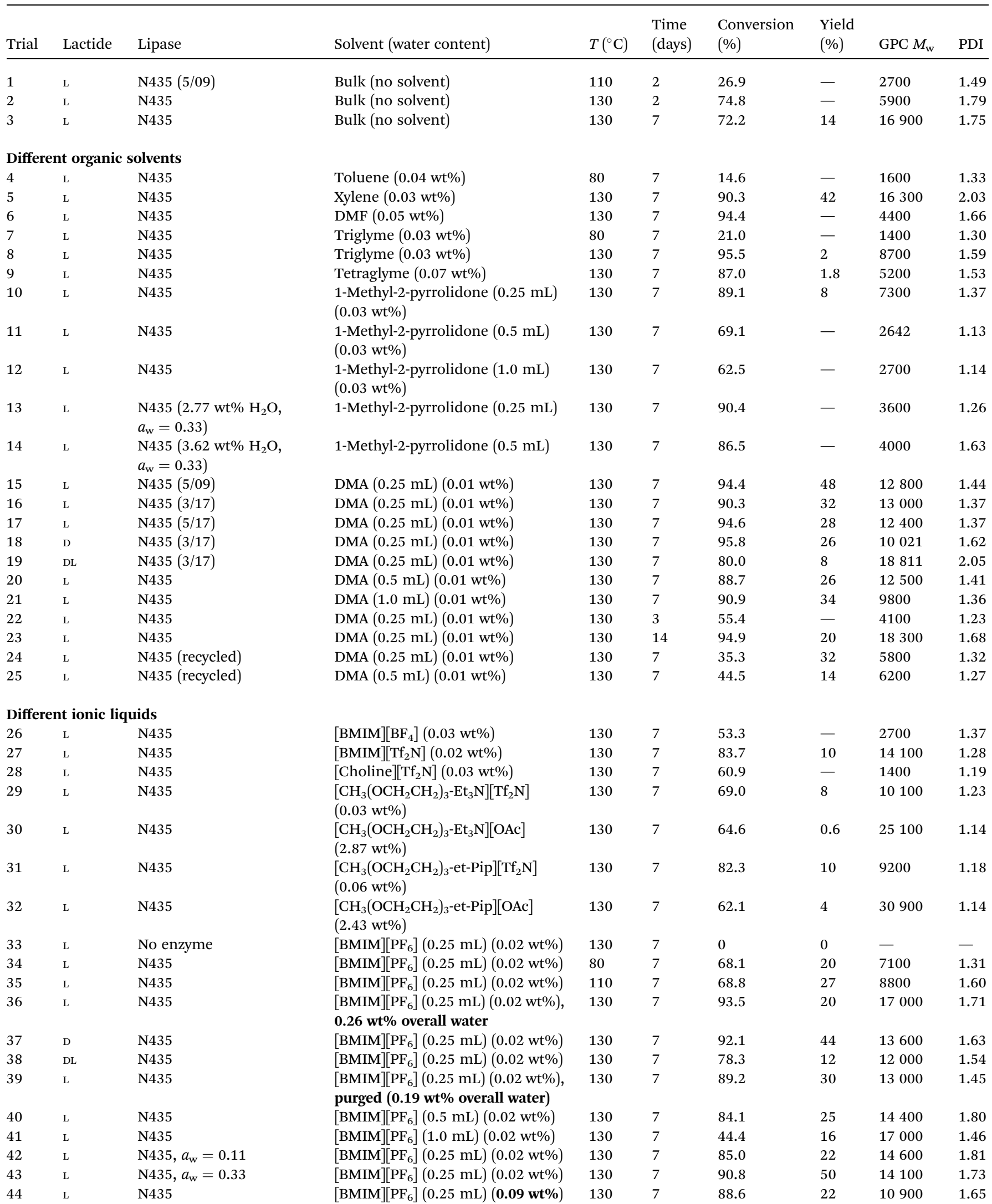


Table 2 (Contd.)

\begin{tabular}{|c|c|c|c|c|c|c|c|c|c|}
\hline Trial & Lactide & Lipase & Solvent (water content) & $T\left({ }^{\circ} \mathrm{C}\right)$ & $\begin{array}{l}\text { Time } \\
\text { (days) }\end{array}$ & $\begin{array}{l}\text { Conversion } \\
(\%)\end{array}$ & $\begin{array}{l}\text { Yield } \\
(\%)\end{array}$ & GPC $M_{\mathrm{w}}$ & PDI \\
\hline 45 & $\mathrm{~L}$ & Free CALB (50 mg) & {$[\mathrm{BMIM}]\left[\mathrm{PF}_{6}\right](0.25 \mathrm{~mL})(0.02 \mathrm{wt} \%)$} & 130 & 7 & 93.5 & 34 & 17500 & 1.80 \\
\hline 46 & $\mathrm{~L}$ & Free CALB (10 mg) & {$[\mathrm{BMIM}]\left[\mathrm{PF}_{6}\right](0.25 \mathrm{~mL})(0.02 \mathrm{wt} \%)$} & 130 & 7 & 39.2 & - & 2800 & 1.12 \\
\hline 47 & $\mathrm{~L}$ & CALB-CLEA (50 mg) & {$[\mathrm{BMIM}]\left[\mathrm{PF}_{6}\right](0.25 \mathrm{~mL})(0.02 \mathrm{wt} \%)$} & 130 & 7 & 92.4 & 22 & 16600 & 1.76 \\
\hline 50 & $\mathrm{~L}$ & $\begin{array}{l}\text { Amano P. fluorescens } \\
\text { lipase }\end{array}$ & {$[\mathrm{BMIM}]\left[\mathrm{PF}_{6}\right](0.25 \mathrm{~mL})(0.02 \mathrm{wt} \%)$} & 130 & 7 & 74.3 & - & 3800 & 1.30 \\
\hline 51 & $\mathrm{~L}$ & Amano lipase PS & {$[\mathrm{BMIM}]\left[\mathrm{PF}_{6}\right](0.25 \mathrm{~mL})(0.02 \mathrm{wt} \%)$} & 130 & 7 & 58.3 & - & 3400 & 1.32 \\
\hline 52 & $\mathrm{~L}$ & Amano lipase PS & Tetraglyme (0.07 wt\%) & 110 & 7 & 96.6 & 6.5 & 11100 & 2.57 \\
\hline 53 & $\mathrm{~L}$ & PPL (Sigma) & {$[\mathrm{BMIM}]\left[\mathrm{PF}_{6}\right](0.25 \mathrm{~mL})(0.02 \mathrm{wt} \%)$} & 130 & 7 & 83.0 & 30 & 11400 & 1.41 \\
\hline 57 & $\mathrm{~L}$ & $\begin{array}{l}\text { lipase from Candida } \\
\text { cylindracea immobilized } \\
\text { in sol-gel-AK }\end{array}$ & {$[\mathrm{BMIM}]\left[\mathrm{PF}_{6}\right](0.25 \mathrm{~mL})(0.02 \mathrm{wt} \%)$} & 130 & 7 & 61.7 & - & 1800 & 1.23 \\
\hline 58 & $\mathrm{~L}$ & $\begin{array}{l}\text { Amano lipase } \mathrm{A} \text { from } \\
\text { Aspergillus niger }\end{array}$ & {$[\mathrm{BMIM}]\left[\mathrm{PF}_{6}\right](0.25 \mathrm{~mL})(0.02 \mathrm{wt} \%)$} & 130 & 7 & 90.0 & 10 & 11000 & 1.36 \\
\hline 59 & $\mathrm{~L}$ & $\begin{array}{l}\text { Amano lipase } \mathrm{A} \text { from } \\
\text { Aspergillus niger }\end{array}$ & Tetraglyme (0.07 wt\%) & 130 & 7 & 92.0 & & 1600 & 1.80 \\
\hline \multicolumn{10}{|c|}{ Different polymerization initiators } \\
\hline 60 & $\mathrm{~L}$ & $\begin{array}{l}\text { N435, } 10 \mu \mathrm{L} \text { ethylene } \\
\text { glycol }\end{array}$ & DMA (0.25 mL) (0.01 wt\%) & 130 & 7 & 95.5 & 18 & 7900 & 1.34 \\
\hline
\end{tabular}

${ }^{a}$ Note: general reaction conditions (or otherwise noted): $0.5 \mathrm{~g}$ lactide, $0.25 \mathrm{~mL}$ solvent, $100 \mathrm{mg}$ immobilized lipase such as Novozym 435 (03/2017 batch as noted in Table 1, unless indicated otherwise) (or $50 \mathrm{mg}$ free lipase), gentle stirring at $130{ }^{\circ} \mathrm{C}$ for 7 days. GPC $M_{\mathrm{w}}$ values were calibrated by polystyrene standards.

provided slightly plasticizing effect. The presence of ILs could lead to the hydrolytic degradation of PLA. Park and Xanthos ${ }^{42}$ evaluated the degradation of PLA (in terms of molecular weight reduction) in the presence of $5 \mathrm{wt} \%$ phosphonium-based ILs (decanoate and tetrafluoroborate), and found the decanoate-IL led to much more severer thermal degradation $\left(160{ }^{\circ} \mathrm{C}\right)$ and hydrolytic degradation $\left(60^{\circ} \mathrm{C}\right.$ in phosphate buffer) than the $\mathrm{BF}_{4}{ }^{-}$-based IL. Li et $a l .{ }^{43}$ observed that acetate-based imidazoliums caused more thermal degradation $\left(170^{\circ} \mathrm{C}\right.$ for $\left.1 \mathrm{~h}\right)$ of PLA than a hydroxide-based IL ([BMIM $][\mathrm{OH}])$ whilst the degradation in $[\mathrm{BMIM}] \mathrm{Cl}$, [BMIM $]\left[\mathrm{BF}_{4}\right]$ and $[\mathrm{BMIM}]\left[\mathrm{HSO}_{4}\right]$ remained at a minimum level; they also found that a longer alkyl chain on the imidazolium cation led to a higher degree of degradation.

Another important factor is the water content in solvents as too much water often leads to unfavorable side reactions including polyester hydrolysis. As shown in earlier studies, with the increase in water content (above $0.2 \mathrm{wt} \%$ (ref. 44 ) or $0.5 \mathrm{wt} \%$ (ref. 45)), the enzymatic ROP rate in bulk increases, but the molecular weight of the polyester decreases. ${ }^{44,45}$ Thurecht et al. ${ }^{46}$ observed a lower molecular weight of polyester with a gradual increase in water content (from 0.004 to $2.004 \mathrm{wt} \%$ ) in supercritical $\mathrm{CO}_{2}$ during the Novozym 435-catalyzed ROP of $\varepsilon$-caprolactone. In our study, when the water content in [BMIM] $\left[\mathrm{PF}_{6}\right]$ increased from $0.02 \mathrm{wt} \%$ (trial 36) to $0.09 \mathrm{wt} \%$ (trial 44 ), the molecular weight dropped from 17000 to 10900 . Although the water content in $[\mathrm{BMIM}]\left[\mathrm{PF}_{6}\right]$ was only $0.02 \mathrm{wt} \%$, the overall water content of the reaction system in trial 36 was determined to be $0.26 \mathrm{wt} \%$ (see Experimental section) because of the presence of water in the enzyme and monomer molecules. If the moisture was purged out of the reaction system after heating the reaction at $130{ }^{\circ} \mathrm{C}$ for $10 \mathrm{~min}$ (trial 39), the overall water content was reduced to $0.19 \mathrm{wt} \%$; however, the molecular weight of PLA decreased to 13000 instead of increasing as predicted. Therefore, minimizing the water content in ROP is critical for achieving a high molecular weight of polyester, however, if the water content becomes too low, the enzymatic 
polymerization may not be efficient since water is also acting as the initiator. ${ }^{17,47}$

In terms of the lipase specificity towards L-, D-, and DL-lactide, we compared the respective reactions in DMA (trials 16, 18, and 19) and in [BMIM] $\left[\mathrm{PF}_{6}\right]$ (trials 36-38) and found that overall L-lactide resulted in the highest molecular weight and yield. Many literature examples concurred that Novozym 435 has the specificity towards L-lactide.,58 However, some groups argued $^{\mathbf{2 0 , 2 1}}$ that CALB exhibits a better selectivity toward D-lactide than L-isomer, whilst lipase from Burkholderia cepacia (i.e. lipase PS) is more specific towards L-lactide. Matsumura et al. ${ }^{18}$ observed no activity of Novozym 435 towards the ROP of D,L-lactide, but a high activity for Pseudomonas cepacia lipase PS and a modest activity for Cundidu cylindruceu lipase and porcine pancreatic lipase (PPL).

\section{Effect of enzyme preparations and different initiators on ROP}

It is known that Novozym-435 contains about $10 \mathrm{wt} \%$ Candida antarctica lipase B (CALB) immobilized on a macroporous acrylic resin. ${ }^{\mathbf{4 9 , 5 0}}$ We used the equivalent amount of free CALB (10 mg vs. $100 \mathrm{mg}$ Novozym 435) and observed a low molecular weight of 2800 (trial 46 in Table 2). However, since free CALB takes much less volume in the reaction mixture than its immobilized form, we were able to add a high amount $(50 \mathrm{mg})$ of free CALB in the ROP reaction. As a result, a high molecular weight (17 500) and a relatively high yield (34\%) were achieved. Other forms of CALB also led to high molecular weights, such as Cross-Linked Enzyme Aggregate (CALB-CLEA, trial 47) and CALB on Immobead 150 (trials 48 and 49). Most other lipases (trials 50-59) showed relatively low activities leading to low molecular weights, except lipase PS (trial 52), PPL (trial 53), and lipase A from Aspergillus niger (trial 58).

We also deployed different initiators (trials 60-64 in Table 2) for the enzymatic polymerization in DMA, such as ethylene glycol, triethylene glycol, glycerol and phenylethanol. But these initiators could not produce the high molecular weights as using water as the initiator (see trials $15-23$ in Table 2).

\section{Enzymatic ROP of $\varepsilon$-caprolactone}

Based on the above understanding of reaction conditions for PLA synthesis, we further evaluated the enzymatic ROP of $\varepsilon$ caprolactone to produce poly( $\varepsilon$-caprolactone) (PCL). A solventfree reaction at $70{ }^{\circ} \mathrm{C}$ for 2 days (trial 1 in Table 3) gave a relatively high $M_{\mathrm{w}} 20700$ and a high yield of 56\% (PDI = 1.45). The similar reactions in DMA (0.25 mL, trials 2 and 3 in Table 3) suggested a higher $M_{\mathrm{w}}$ up to 23000 , but even higher DMA contents (trials 4 and 5) caused lower molecular weights, which is in line with earlier study on PLA synthesis. A longer reaction time (7 days, trials 6 and 7$)$ and a higher temperature $\left(130{ }^{\circ} \mathrm{C}\right.$, trials 8 and 9) led to lower molecular weights, possibly due to the polyester degradation under these conditions. Surprisingly, free CALB (trial 10 in Table 3) failed to synthesize a high molecular weight of PCL, which is in contrast to the PLA

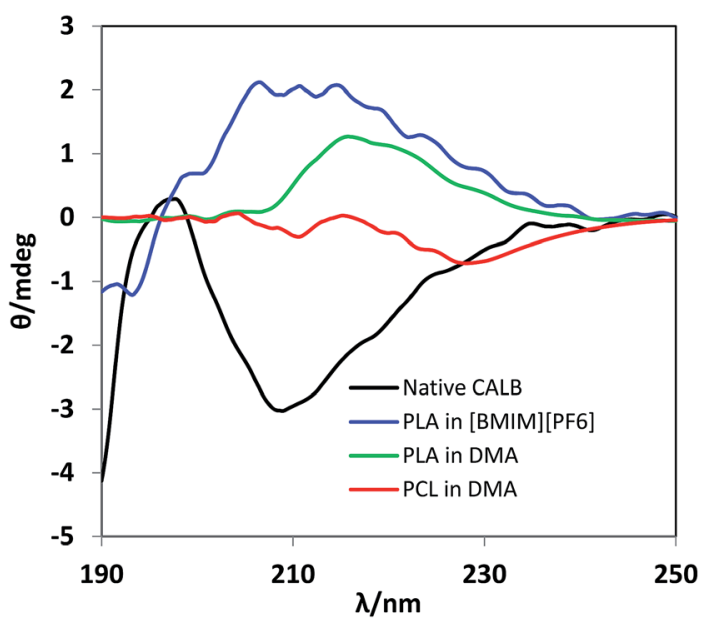

Fig. 1 Far-UV CD spectra of free CALB before and after reactions

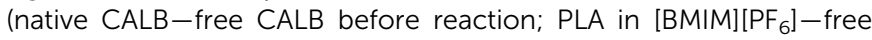
CALB after the ROP of $L$-lactide in [BMIM] $\left[\mathrm{PF}_{6}\right]$ for 7 days at $130{ }^{\circ} \mathrm{C}$; PLA in DMA-free CALB after the ROP of L-lactide in DMA for 7 days at $130{ }^{\circ} \mathrm{C}$; PCL in DMA-free CALB after the ROP of $\varepsilon$-caprolactone in DMA for 2 days at $70^{\circ} \mathrm{C}$ ).

Table 3 Enzymatic ROP of $\varepsilon$-caprolactone under different reaction conditions ${ }^{a}$

\begin{tabular}{|c|c|c|c|c|c|c|c|c|c|}
\hline Trial & Solvent (water content) & $T\left({ }^{\circ} \mathrm{C}\right)$ & Time (days) & Conversion $(\%)$ & Yield (\%) & GPC $M_{\mathrm{w}}$ & PDI & GPC $M_{\mathrm{n}}$ & ${ }^{1} \mathrm{H}$ NMR $M_{\mathrm{n}}$ \\
\hline 1 & No solvent & 70 & 2 & 95.7 & 56 & 20700 & 1.45 & 14300 & 10400 \\
\hline 2 & DMA $(0.25 \mathrm{~mL})(0.01 \mathrm{wt} \%)$ & 70 & 1 & 96.5 & 34 & 23000 & 1.43 & 16000 & 11200 \\
\hline 4 & DMA $(0.50 \mathrm{~mL})(0.01 \mathrm{wt} \%)$ & 70 & 2 & 97.0 & 44 & 18100 & 2.16 & 8366 & 14200 \\
\hline 5 & DMA $(1.0 \mathrm{~mL})(0.01 \mathrm{wt} \%)$ & 70 & 2 & 98.1 & 48 & 20100 & 1.51 & 13287 & 9400 \\
\hline 6 & DMA $(0.25 \mathrm{~mL})(0.01 \mathrm{wt} \%)$ & 70 & 7 & 96.8 & 50 & 18700 & 2.24 & 8400 & 9900 \\
\hline 9 & DMA $(0.25 \mathrm{~mL})(0.01 \mathrm{wt} \%)$ & 130 & 2 & 95.3 & 48 & 14600 & 1.92 & 7600 & 8900 \\
\hline 10 & $\begin{array}{l}\text { DMA }(0.25 \mathrm{~mL})(0.01 \mathrm{wt} \%), 50 \mathrm{mg} \text { free } \\
\text { CALB }\end{array}$ & 70 & 2 & 43.4 & 2 & 2968 & 1.31 & 2258 & 2200 \\
\hline 11 & {$[\mathrm{BMIM}]\left[\mathrm{PF}_{6}\right](0.25 \mathrm{~mL})(0.02 \mathrm{wt} \%)$} & 70 & 2 & 88.4 & 46 & 20700 & 1.86 & 11100 & 10500 \\
\hline
\end{tabular}

${ }^{a}$ Note: general reaction conditions (or otherwise noted): $0.5 \mathrm{~g} \varepsilon$-caprolactone, $0.25 \mathrm{~mL}$ solvent, $100 \mathrm{mg}$ Novozym 435 (or otherwise noted), gentle stirring at $70{ }^{\circ} \mathrm{C}$. GPC $M_{\mathrm{w}}$ values were calibrated by polystyrene standards. 
reaction (trial 45 in Table 2 ). The use of $[\mathrm{BMIM}]\left[\mathrm{PF}_{6}\right]$ produced a comparable molecular weight $\left(M_{\mathrm{w}} 20700\right)$ as in bulk, but a lower yield of $46 \%$.

To understand the severity of the reaction conditions on lipase structures, circular dichroism (CD) spectra of CALB were recorded in the far-UV region (190-240 nm) for native CALB, and CALB samples after PLA and PCL synthesis (Fig. 1). The CD spectrum of native CALB shows a characteristic minimum band at $208 \mathrm{~nm}$ and a positive band at about $197 \mathrm{~nm}$, which corresponding to about $34 \%$-helical structure. ${ }^{51,52}$ However, following the reactions of PLA and PCL syntheses, all CALB lost their characteristic bands indicating the disrupted secondary structures of lipase after the severe reaction conditions.

\section{Confirmation of polyester structures and optical rotation}

The structures of poly(L-lactide) (PLLA) and poly(D-lactide) (PDLA) were confirmed by ${ }^{1} \mathrm{H}$ and ${ }^{13} \mathrm{C}$ NMR spectra, and FT-IR spectra, as well as by the optical rotation of these polyesters. Fig. S1(a)-(d) $\dagger$ clearly confirmed the identities of PLLA and PDLA samples. As illustrated by Scheme 1, L-lactide shows two ${ }^{1} \mathrm{H}$ NMR peaks at 1.67 ppm (a) and 5.04 ppm (b) while PLA shows two characteristic peaks at $1.57 \mathrm{ppm}\left(\mathrm{a}^{\prime}\right)$ and $5.17 \mathrm{ppm}\left(\mathrm{b}^{\prime}\right) .{ }^{12}$ In addition, major ${ }^{13} \mathrm{C}$ NMR signals for PLA include 169.7 ppm $(\mathrm{C}=\mathrm{O}), 69.1 \mathrm{ppm}(\mathrm{C}-\mathrm{H})$, and $16.7 \mathrm{ppm}\left(\mathrm{CH}_{3}\right)$, and for L-lactide monomer, peaks are $169.6 \mathrm{ppm}(\mathrm{C}=\mathrm{O}), 69.0 \mathrm{ppm}(\mathrm{C}-\mathrm{H})$ and $16.7 \mathrm{ppm}\left(\mathrm{CH}_{3}\right){ }^{22}$ As shown in Fig. S2, $\uparrow$ the IR spectra of the PLLA and PDLA suggest peaks at 3000 and 2950 (C-H stretching vibration), 1760 (C-O stretching vibration), 1460 and 1380 (C-H bending vibration), and 1190 and $1090 \mathrm{~cm}^{-1}$ (C-O stretching vibration), respectively. ${ }^{12,53}$ The specific rotation $[\alpha]_{\mathrm{D}}\left(25^{\circ} \mathrm{C}, \mathrm{CHCl}_{3}, 0.861 \mathrm{~g} / 100 \mathrm{~mL}\right)$ of PLLA was reported to be $-156^{\circ} .^{54}$ Our PLLA (trial 1 in Table 1 ) and PDLA (trial 37 in Table 2) were determined to be $-105^{\circ}$ and $+102^{\circ}$ respectively, suggesting both polyesters are primarily isotactic. As shown in Fig. S1(e) and (f), $\dagger^{1} \mathrm{H}$ NMR peaks for PCL are $4.06 \mathrm{ppm}\left(\mathrm{t}, 2 \mathrm{H},-\mathrm{CH}_{2} \mathrm{O}-\right], 2.30 \mathrm{ppm}\left(\mathrm{t}, 2 \mathrm{H},-\mathrm{CH}_{2} \mathrm{O}_{2}-\right)$, $1.64 \mathrm{ppm}\left(\mathrm{m}, 4 \mathrm{H},-\left(\mathrm{CH}_{2}\right)_{2}-\right), 1.39 \mathrm{ppm}$ (qunit, $\left.\left.2 \mathrm{H},-\mathrm{CH}_{2}-\right]\right) ;{ }^{13} \mathrm{C}$ NMR peaks are 173.7 ppm, 64.3 ppm, 34.2 ppm, $28.4 \mathrm{ppm}$, $25.6 \mathrm{ppm}$, and 24.7 ppm. FT-IR bands (see Fig. S2 $\dagger$ ) are $3420\left(\nu_{\mathrm{OH}}\right)$, $2947\left(\nu_{\mathrm{CH}}\right), 1721\left(\nu_{\mathrm{C}=\mathrm{O}}\right), 1171 \mathrm{~cm}^{-1}\left(\delta_{\mathrm{O}-\mathrm{C}=\mathrm{O}}\right)$. These characterizations are in line with literature data. ${ }^{55,56}$

\section{Evaluating the reliability of $M_{\mathbf{n}}$ from GPC}

The Duda group ${ }^{9,57}$ and Soum group ${ }^{58}$ pointed out that the gel permeation chromatography (GPC) or size exclusion

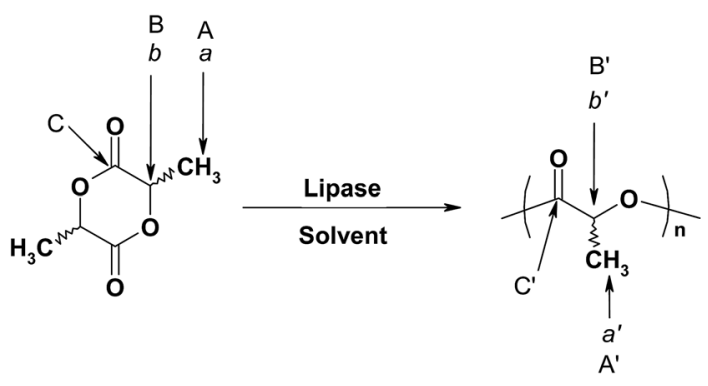

Scheme 1 Enzymatic ROP of lactide. chromatography (SEC) using polystyrene standards tend to overestimated the value of $M_{\mathrm{n}}$ of polylactide; therefore, the experimental values need to be adjusted by a coefficient of $0.58,57,58$ or 0.68 (ref. 9) (at least up to $M_{\mathrm{n}} \leq 2 \times 10^{4}$, for the set of TSKgel G $2000 \mathrm{HXL}$ and $6400 \mathrm{HXL}$ columns with $\mathrm{CH}_{2} \mathrm{Cl}_{2}$ as an eluent). The correcting coefficients for polylactones are as the following: $0.56 \pm$ 0.05 for poly( $\varepsilon$-caprolactone), $0.57 \pm 0.05$ for poly( $\delta$-valerolactone), $0.54 \pm 0.05$ for $\operatorname{poly}(\beta$-butyrolactone $)$, and $0.54 \pm 0.05$ for poly $(\delta$ caprolactone). ${ }^{58}$

To verify the reliability of molecular weight obtained from GPC analysis, we analyzed a commercial poly(D,L-lactide) known as Resomer ${ }^{2} \mathrm{R} 203 \mathrm{H}$ with reported $M_{\mathrm{w}} 18000-24000$, and determined its $M_{\mathrm{w}}$ as 27000 , which is not too far from the reported value. In Table 3 , we compared the $M_{\mathrm{n}}$ values from GPC analysis with those from the ${ }^{1} \mathrm{H}$ NMR method, and found these values are much closer than that using the above-mentioned correcting coefficients. Therefore, the GPC method seems reliable for determining the molecular weights of PLA and PCL.

\section{Conclusion}

PLAs with weight-averaged molecular weight $\left(M_{\mathrm{w}}\right)$ values below 1 $\times 10^{4}$, between $1 \times 10^{4}$ and $1 \times 10^{5}$, or above $1 \times 10^{5}$ are considered low molecular weight (LMW), medium molecular weight (MMW), and high molecular weight (HMW) respectively. ${ }^{59}$ Our PLAs have the highest molecular weights $\left(M_{\mathrm{w}}\right)$ in the range of 10 000-20 000, which places them as MMW polyesters. This type of polyesters could be used as the soft block of thermoplastic elastomers, or carriers for controlled drug delivery and release.

Our study suggests that the key factors controlling the ROP reactions include the types of lipases and solvents, the solvent concentration, water contents in enzymes, substrates and solvents, and the reaction temperature. DMA and $[\mathrm{BMIM}]\left[\mathrm{PF}_{6}\right]$ at low concentrations are suitable for the ROPs of lactides and $\varepsilon$-caprolactone leading to $M_{\mathrm{w}}$ around 20000 and moderately high yields. Molecular weights reported in literatures for similar enzymatic ROP methods (see Table $\mathrm{S} 1 \uparrow$ and reviews ${ }^{17,48,60}$ ) are not always in good agreement even in terms of magnitudes; this could be due to different reaction batches containing different amounts of water in enzymes and solvents, and using different methods for determining the molecular weight. In addition, the precipitation method could cause some discrepancies of molecular weights since precipitation of polyesters from reaction mixture could lead to an increase in molecular weight and a decrease in PDI. ${ }^{61}$

\section{Conflicts of interest}

There are no conflicts to declare.

\section{Acknowledgements}

HZ acknowledges the supports by the Henry Dreyfus TeacherScholar Award (2012-2018), and the ACS Petroleum Research Fund (PRF\# 54875-UR9). 


\section{References}

1 K. M. Nampoothiri, N. R. Nair and R. P. John, Bioresour. Technol., 2010, 101, 8493-8501.

2 R. E. Drumright, P. R. Gruber and D. E. Henton, Adv. Mater., 2000, 12, 1841-1846.

3 R. Auras, B. Harte and S. Selke, Macromol. Biosci., 2004, 4, 835-864.

4 P. Zinck, Rev. Environ. Sci. Bio/Technol., 2009, 8, 231-234.

5 A.-C. Albertsson and I. K. Varma, Biomacromolecules, 2003, 4, 1466-1486.

6 U. Piotrowska and M. Sobczak, Molecules, 2015, 20, 1-23.

7 M. Ajioka, K. Enomoto, K. Suzuke and A. Yamaguchi, Bull. Chem. Soc. Jpn., 1995, 68, 2125-2131.

8 S. I. Moon, I. Taniguchi, M. Miyamoto, Y. Kimura and C. W. Lee, High Perform. Polym., 2001, 13, 189-196.

9 A. Kowalski, J. Libiszowski, A. Duda and S. Penczek, Macromolecules, 2000, 33, 1964-1971.

10 J. Pretula, S. Slomkowski and S. Penczek, Adv. Drug Delivery Rev., 2016, 107, 3-16.

11 H. Zhao, J. Chem. Technol. Biotechnol., 2018, 93, DOI: 10.1002/jctb.5444.

12 M. Yoshizawa-Fujita, C. Saito, Y. Takeoka and M. Rikukawa, Polym. Adv. Technol., 2008, 19, 1396-1400.

13 R. García-Arrazola, D. A. López-Guerrero, M. Gimeno and E. Bárzana, J. Supercrit. Fluids, 2009, 51, 197-201.

14 M. Mena, S. Chanfreau, M. Gimeno and E. Bárzana, Bioprocess Biosyst. Eng., 2010, 33, 1095-1101.

15 S. Chanfreau, M. Mena, J. R. Porras-Domínguez, M. RamírezGilly, M. Gimeno, P. Roquero, A. Tecante and E. Bárzana, Bioprocess Biosyst. Eng., 2010, 33, 629-638.

16 A. Idris and A. Bukhari, Biotechnol. Adv., 2012, 30, 550-563.

17 A.-C. Albertsson and R. K. Srivastava, Adv. Drug Delivery Rev., 2008, 60, 1077-1093.

18 S. Matsumura, K. Mabuchi and K. Toshima, Macromol. Rapid Commun., 1997, 18, 477-482.

19 S. Matsumura, K. Tsukada and K. Toshima, Int. J. Biol. Macromol., 1999, 25, 161-167.

20 M. Takwa, M. W. Larsen, K. Hult and M. Martinelle, Chem. Commun., 2011, 47, 7392-7394.

21 S. W. Duchiron, E. Pollet, S. Givry and L. Avérous, RSC Adv., 2015, 5, 84627-84635.

22 D. Omay and Y. Guvenilir, Biocatal. Biotransform., 2013, 31, 132-140.

23 H. Zhao, G. A. Baker, Z. Song, O. Olubajo, T. Crittle and D. Peters, Green Chem., 2008, 10, 696-705.

24 S. Tang, G. A. Baker, S. Ravula, J. E. Jones and H. Zhao, Green Chem., 2012, 14, 2922-2932.

25 U. Piotrowska, M. Sobczak, E. Oledzka and C. Combes, J. Appl. Polym. Sci., 2016, 133, 43728.

26 K. Sha, L. Qin, D. Li, X. Liu and J. Wang, Polym. Bull., 2005, 54, 1-9.

27 E. Ozsagiroglu, B. Iyisan and Y. Avcibasi-Guvenilir, Afr. J. Biotechnol., 2012, 11, 12688-12696.

28 M. Mena, A. López-Luna, K. Shirai, A. Tecante, M. Gimeno and E. Bárzana, Bioprocess Biosyst. Eng., 2013, 36, 383-387.
29 K. A. Barrera-Rivera, A. Flores-Carreón and A. MartínezRicha, J. Appl. Polym. Sci., 2008, 109, 708-719.

30 F.-X. Dong, L. Zhang, X.-Z. Tong, H.-B. Chen, X.-L. Wang and Y.-Z. Wang, J. Mol. Catal. B: Enzym., 2012, 77, 46-52.

31 G. A. R. Nobes, R. J. Kazlauskas and R. H. Marchessault, Macromolecules, 1996, 29, 4829-4833.

32 M. Sobczak, J. Appl. Polym. Sci., 2012, 125, 3602-3609.

33 Y. Mei, A. Kumar and R. Gross, Macromolecules, 2003, 36, 5530-5536.

34 C. S. Lee, M. T. Ru, M. Haake, J. S. Dordick, J. A. Reimer and D. S. Clark, Biotechnol. Bioeng., 1998, 57, 686-693.

35 M. Dolman, P. J. Halling, B. D. Moore and S. Waldron, Biopolymers, 1997, 41, 313-321.

36 P. M. Johnson, S. Kundu and K. L. Beers, Biomacromolecules, 2011, 12, 3337-3343.

37 M. Eckstein, M. Sesing, U. Kragl and P. Adlercreutz, Biotechnol. Lett., 2002, 24, 867-872.

38 G. V. Chowdary and S. G. Prapulla, Process Biochem., 2002, 38, 393-397.

39 P. J. Halling, Biotechnol. Tech., 1992, 6, 271-276.

40 A. E. Polloni, J. G. Veneral, E. A. Rebelatto, D. de Oliveira, J. V. Oliveira, P. H. H. Araújo and C. Sayer, J. Supercrit. Fluids, 2017, 119, 221-228.

41 L. Gardella, D. Furfaro, M. Galimberti and O. Monticelli, Green Chem., 2015, 17, 4082-4088.

42 K. I. Park and M. Xanthos, Polym. Degrad. Stab., 2009, 94, 834-844.

43 X. Li, Q. Zhou, K. Yang and Y. Wang, Chem. Pap., 2014, 68, 1375-1380.

44 K. S. Bisht, L. A. Henderson, R. A. Gross, D. L. Kaplan and G. Swift, Macromolecules, 1997, 30, 2705-2711.

45 K. S. Bisht, Y. Y. Svirkin, L. A. Henderson, R. A. Gross, D. L. Kaplan and G. Swift, Macromolecules, 1997, 30, 77357742.

46 K. J. Thurecht, A. Heise, M. deGeus, S. Villarroya, J. Zhou, M. F. Wyatt and S. M. Howdle, Macromolecules, 2006, 39, 7967-7972.

47 S. Namekawa, S. Suda, H. Uyama and S. Kobayashi, Int. J. Biol. Macromol., 1999, 25, 145-151.

48 S. Kobayashi, Macromol. Rapid Commun., 2009, 30, 237-266.

49 F. C. Loeker, C. J. Duxbury, R. Kumar, W. Gao, R. A. Gross and S. M. Howdle, Macromolecules, 2004, 37, 2450-2453.

50 F. Deng and R. A. Gross, Int. J. Biol. Macromol., 1999, 25, 153159.

51 T. De Diego, P. Lozano, S. Gmouh, M. Vaultier and J. L. Iborra, Biomacromolecules, 2005, 6, 1457-1464.

52 J. Uppenberg, M. T. Hansen, S. Patkar and T. A. Jones, Structure, 1994, 2, 293-308.

53 S. Matsumura, K. Mabuchi and K. Toshima, Macromol. Symp., 1998, 130, 285-304.

54 F. Chabot and M. Vert, Polymer, 1983, 24, 53-59.

55 K. A. Barrera-Rivera, Á. Marcos-Fernández, R. Vera-Graziano and A. Martínez-Richa, J. Polym. Sci., Part A: Polym. Chem., 2009, 47, 5792-5805.

56 J. Cayuela, V. Bounor-Legaré, P. Cassagnau and A. Michel, Macromolecules, 2006, 39, 1338-1346. 
57 A. Kowalski, A. Duda and S. Penczek, Macromolecules, 1998, 31, 2114-2122.

58 M. Save, M. Schappacher and A. Soum, Macromol. Chem. Phys., 2002, 203, 889-899.

59 H. Tsuji, Adv. Drug Delivery Rev., 2016, 107, 97-135.
60 C. Jérôme and P. Lecomte, Adv. Drug Delivery Rev., 2008, 60, 1056-1076.

61 R. Marcilla, M. de Geus, D. Mecerreyes, C. J. Duxbury, C. E. Koning and A. Heise, Eur. Polym. J., 2006, 42, 12151221. 